\title{
Faculty Service As Board Members In The Non-Profit Organizational Arena: An Act Of Altruism Complicated By Sarbanes Oxley
}

Gregory P. Trudeau, (Email: gtrudeau@uwsuper.edu), University of Wisconsin-Superior

\begin{abstract}
Throughout higher education, a common approach to evaluate faculty consists of three components: scholarship, teaching, and service. The service component can be broadly interpreted to encompass two themes, service on campus via committee assignments or service off campus with organizations in the surrounding community. Serving as a board member for a local non-profit organization often fulfills the required service component. Unfortunately, many board members do not have a clear understanding of what this responsibility entails. This paper will look at the responsibilities a board member assumes within the non-profit organization. Consideration will also be given to these responsibilities from the perspective of Sarbanes-Oxley.
\end{abstract}

\section{CAMPUS OR COMMUNITY SERVICE}

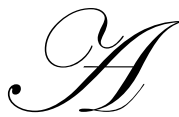

common component in evaluating Faculty performance is the service component. Institutions vary in regard to which component is weighed more heavily with large research institutions weighing scholarship the heaviest, then teaching, and finally a smaller weight given to service. Other institutions will have teaching weigh the most, followed by scholarship, and again service as the smallest weight of the three. For example, at the University of Wisconsin - Superior, within the Department of Business and Economics, the bylaws indicate the following weights for retention, promotion, and tenure: teaching $60 \%-75 \%$ and scholarship/service $25 \%$ 40\%. Article II of the Department of Business and Economics Bylaws are reproduced in Appendix A for reference.

Regardless of the weights given to scholarship or teaching, a service component is usually required. A common interpretation of the service component consists of two distinct categories. One is service within the University community and the other being service within the community. While not exhaustive, the Department of Business and Economics at the University of Wisconsin - Superior defines the service element to include: invited lectures or presentations to members of community organizations, participation on community boards of advisors, volunteerism activities that build ties between gown and town, membership and participation on committees within the university community, and special projects or ad hoc appointments.

Given the voluntary spirit and philanthropic beliefs of many faculty members, a natural avenue to pursue in fulfilling the service requirement is service on a local non-profit board. Other faculty members may take a board position for pure altruistic reasons. In both situations, this gown to town linkage is a natural and mutually advantageous arrangement. The faculty member who possesses desirable knowledge in one or more specific disciplines can bring that knowledge to the organization, while the organization helps the faculty member fulfill the required service component. 


\section{DUTIES OF A BOARD}

In reviewing the literature addressing the responsibilities of a governance board, I found a common distinction between the responsibilities of a board as a collective group and the responsibilities of an individual board member. This section of the paper lists the responsibilities of the board as a collective group and the next section discusses the responsibilities of the individual board member.

Richard T. Ingram (2003) compiled a concise and clear list of board duties. Ingram points out that while “...there is no one-size fits all model to governance, there are fundamental responsibilities that hold true for almost every board" (Ingram, pg viii). Ingram's list includes:

1. Determine the Organization's Mission and Purpose.

Through the inclusion and consultation with the organizations members, staff, and other stakeholders, the board has the responsibility to adopt the Mission of the institution. This mission statement should drive the planning, budgeting, and rewarding of decisions within the organization.

2. Select the Chief Executive.

The board in consultation with appropriate stakeholders should make the final selection of the Chief Executive. In addition to selecting the CEO, the board should set the compensation package and be sure the position description, responsibilities and expectations are clearly communicated to the new CEO.

3. Provide Proper Financial Oversight.

Based upon achieving the goals and objectives of the institution's mission, an annual budget needs to be developed, adopted, and communicated throughout the organization. While communication of the adopted budget is management's responsibilities, it is the board's responsibility to help develop and adopt the budget.

4. $\quad$ Ensure Adequate Resources.

Regardless of the nature of the non-profit, the board has the responsibility to ensure that adequate resources are available. For non-service entities, resources are obtained through contributions. For organizations that are service oriented, the board should ensure that adequate resources are available through the budgetary process. In this case the board members should take an active role by contributing to the organization and helping in the fund raising events to the extent possible.

5. Ensure Legal and Ethical Integrity and Maintain Accountability.

Recent organizations like Enron, Global Crossing, and Arthur Anderson have captured the headlines with their almost unbelievable frauds, embezzlements, or breach of public trust. One common element runs through the many negative headlines in recent years-- a lack of appropriate oversight. The outcome of this lack of oversight is the now infamous Sarbanes Oxley Act, subsequently discussed in this paper. This oversight is the responsibility of the organization's board.

6. Ensure Effective Organizational Planning.

Based upon the organization's mission, specific planning needs to take place in order to establish objectives and goals. This long-range planning is often done through the strategic planning process. Although strategic planning can be conducted in a variety of manners, it is the board's responsibility to see that strategic planning is taking place and to take an active role in the process.

7. Recruit and Orient New Board Members and Assess Board Performance.

Excellent recruiting and orientation of new board members is the underpinning of the future strength of the board. In addition to good recruiting and orientation practices, a board needs to periodically assess its performance. This assessment should be done regarding the board in total every five to seven years and to individual board members at re-election time. Should board members feel another member's performance is not adequate prior to re-election, an intervening assessment should be performed to allow this individual the opportunity to improve on his or her performance.

8. Enhance the Organization's Public Standing.

Board members are not only visible to the members within the organization but also are ambassadors of the organization to the community at large. In this regard, board members have a responsibility to conduct themselves in the utmost professional manner.

9. Determine, Monitor, and Strengthen the Organization's Programs and Services. 
On at least a monthly basis, board members should receive quantitative and/or qualitative information to monitor the organization's performance. This monitoring should be consistent with the goals and objectives of the strategic planning process and, therefore, supportive of the organization's mission.

10. Support the Chief Executive and Assess His or Her Performance.

Board members should be supportive of the Chief Executive and his or her needs to achieve the performance initially indicated by the board upon the CEO's hiring. In addition, periodic assessment of the CEO's performance is also necessary. The board or a subcommittee of the full board should carry out this assessment.

\section{DUTIES OF THE INDIVIDUAL BOARD MEMBER}

Specific duties of individual board members evolve out of the collective board responsibilities listed above and may include:

1. Gaining an understanding of the organizations mission, goals and objectives.

2. Understanding the environment within which the organization operates.

3. Preparing for meetings associated with the organization.

4. Maintaining confidentiality with proprietary items of the organization or its members.

5. Avoiding situations whereby special considerations are afforded a board member.

6. Obtaining an understanding of the organizations financial statements in helping the board fulfill its fiduciary responsibility.

\section{SARBANES OXLEY}

In the 1980's the scandals consisting of junk bonds, insider trading, and misleading derivative instruments were prevalent. Leveraged buy-outs and the savings and loans debacle coupled with the stock market crash of the late 1980 's brought the scandals of the 1990's (Guerra). In the early 2000's numerous companies were managing earnings through weak accounting rules. "...Enron and Krispy Kreme reportedly used off balance sheet financing to obscure long-term debt, Global Crossing swapped underwater cable rights to enhance revenue, and IBM netted the gain on an asset sale against overhead expenses (Ricchiute)." In addition to these corporate scandals, the public confidence in auditor's independence was severely damaged. This damage was caused by the publicity brought to the fact that nonaudit service fees compromise an auditor's independence. The Wall Street Journal (Weil and Tannenbaum) reported that in a study of 307 of the Standard and Poors 500 companies that made disclosures, all reported paying their auditors a non-audit fee. In fact, these non-audit fees amounted to $\$ 2.65$ billion while the audit fees amounted to $\$ 909$ million. In other words, the non-audit fees were three times the audit fees.

Further, the bankruptcy of Enron after management admitted to increasing earnings by approximately $\$ 600$ million was the largest bankruptcy at that time with assets of $\$ 62$ billion. However, less than one year later, WorldCom filed for bankruptcy with assets of $\$ 100$ billion. WorldCom subsequently was found to have been involved in massive fraud, contributing to its eventual bankruptcy. Interestingly, Arthur Anderson, one of the Big Five accounting firms at that time, audited both of these corporations. Arthur Anderson eventually ceased to exist when it was found guilty of obstruction of justice in its dealings with Enron, (Arens, Elder, \& Beasley, 2004, p.2).

The public's concern regarding the auditor's lack of independence brought on by the high non-audit fees coupled with the corporate scandals of the 1990's and 2000's prompted the SEC to conduct hearings. These hearings resulted in Congress passing the Sarbanes-Oxley Act in 2002. This act established the Public Company Accounting Oversight Board.

According to W.H. Donaldson (2003), SEC Chairman, this act is the "most important securities legislation since the original federal securities laws of the 1930's," and will impact a "dramatic change across the corporate landscape to reestablish investor confidence in the integrity of corporate disclosures and financial reporting." 
Sarbanes-Oxley applies mainly to publicly traded companies by broadening the board members' role in overseeing financial transactions and auditing procedures. Despite the application toward publicly traded companies, non-profits probably will become subject to this act or another similar act drafted specifically toward them. In fact, BoardSouce (2003) indicates "Indeed, some state attorney generals are already proposing that elements of the Sarbanes-Oxley Act be applied to nonprofit organizations." Further, it would appear logical that if publicly traded companies hold their board members to a higher level of responsibility, the non-profit organizations must follow suit, or risk being viewed as having a substandard quality of organizational governance.

Judy Cooper, the Credit Unions National Association's (CUNA) senior vice president and associate general counsel, in the November, 2004 edition of Credit Union Magazine recognized that one outcome of the regulation is the increased recognition by all companies of the need for good corporate governance, along with the evolution of governance best practices. The National Credit Union Administration, in a letter to federal credit unions, recommended consideration of the provisions of Sarbanes-Oxley as an example of best practices.

Section 404 of Sarbanes-Oxley requires management to assess a company's internal control. The issue of assessing internal control is not new and in fact was the thrust of the Treadway Commission formed in 1985. The result of the National Commission on Fraudulent Financial Reporting was the Committee of Sponsoring Organizations or COSO. COSO created a conceptual framework providing subjective concepts of effective internal control. This framework includes assessing risk and assessing the control environment. In fact, the control environment is viewed as the foundation for the entire organization's internal control and for the other components of internal control as outlined by COSO (Deloitte \& Touche, 2004). This control environment starts with the board and is carried down through the entire organization. This implies board members need to be fully aware of all their fiduciary responsibilities or the control environment is substantially weakened.

\section{CONCLUSION}

In conclusion, it is the opinion of this author that in offering their expertise in a mutually beneficial role as a board member in a non-profit organization, faculty have unknowingly taken on an increase amount of fiduciary responsibility. This increased responsibility as explained in detail in the lengthy Sarbanes-Oxley Act, although not legislated for non-profits, is being taunted as the new benchmark for non-profit organizations. Finally, an inordinate percent of faculty, would appear to be exposed to this risk as faculty are heavily recruited by non-profit organizations to serve as board members. Therefore, what faculty must do who are board members on non-profit organizations is to bring this issue up at their board meetings and inquire about training for both the organization and the board. It is after all, one of their new responsibilities under Sarbanes-Oxley, section 404, that requires management's assessment of a company's internal control.

\section{REFERENCES}

1. Arens, A.A., Elder, R, J., \& Beasley, M.S. (2004). Overview of the Sarbanes-Oxley Act of 2002 with Other Changes in Auditing and the Public Accounting Profession, Upper Saddle River, New Jersey: Pearson Prentice Hall.

2. Begin, S. (2004). Nonprofits weigh new governance guidelines, Crain's Detroit Business, June 14, 2004 v20 i24 p26.

3. Cahill, J., (1994). Board of Directors: Duties and Responsibilities, Volunteer Achievement Program.

4. Cahill, J., (1994). Board and Management Policies, Volunteer Achievement Program.

5. Deloitte \& Touche LLP, Ernst \& Young LLP, KPMG LLP, \& PricewaterhouseCoopers LLP. (2004).

Perspectives on Internal Control Reporting, A Resource for Financial Market Participants.

6. Deloitte \& Touche LLP, Ernst \& Young LLP, KPMG LLP, \& PricewaterhouseCoopers LLP. (2004). Internal Control Over Financial Reporting, An Investor Resource.

7. Donaldson, W.H. (2003). SEC Chairman, Testimony Concerning Implementation of the Sarbanes Oxley Act before the Senate Committee on Banking, Housing and Urban Affairs, September 9.

8. Don’t Dismiss Sarbanes-Oxley, (2004). Credit Union Magazine, November 2004, p22. 
9. Guerra, Jorge E. (2003). The Sarbanes-Oxley Act of 2002 and Evolution of the Corporate Governance Process, www.imaknowledge.org/sox, 12/1/03.

10. Ingram, Richard T. (2003). Ten Basic Responsibilities of Nonprofit Boards, BoardSource.

11. McConnell, D. K., \& Banks, G. Y. (2003). How Sarbanes-Oxley Will Change the Audit Process, Journal of Accountancy, September, p49.

12. Ricchiute, David N. (2006). Auditing Thomson South-Western, p 38-40.

13. The Sarbanes-Oxley Act and Implications for Nonprofit Organizations, (2003). www.boardsource.org, www.IndependentSector.org, BoardSource and Independent Sector.

14. The Information That Boards Really Need, (2003). MIT Sloan Management Review, Spring, v44, p71 (6).

15. Weil, J. and Tannenbaum J., (2001). Big Companies Pay Audit Firms More for Other Services, The Wall Street Journal, April 10, p. C-1-C-2.

16. Weiner, S. (2003). Proposed Legislation: Its Impact on Not-for-Profit Board Governance, The CPA Journal Nov, v73, i11, p56 (3).

\section{APPENDIX A}

\section{Article II: Department Retention, Promotion, Salary Adjustment, Tenure, and Post-Tenure Criteria}

The Department Chair will conduct a face-to-face review with each Department member on a regular basis. Additional interim meetings can be arranged to discuss progress and revise objectives. The Chair will meet at least annually with individual untenured faculty members to discuss their progress toward tenure and also on an annual basis with academic staff. In accordance with UW-System policy, Extension activities will be considered in the evaluation for those Department members who are engaged in Extension work.

Recognizing that efforts and successes in different evaluation categories will vary by individual and time frame, the person being evaluated will identify the weights he or she wishes to be used in each of the following categories, within the established ranges. The Personnel Committee will recommend decisions regarding retention, promotion, salary adjustment, tenure, and post-tenure to the appropriate administrator following University policy guidelines.

\section{Mentors}

It is strongly recommend that mentors be assigned to each tenure-track faculty member to guide the new faculty member throughout the probationary period. Effective service as a mentor should be recognized as a key element of the faculty member's Department and University service during the salary and retention reviews.

I. Teaching: $(60 \%-75 \%)$ Any or all of the following may be considered:
a. Advisement
b. Extent to which you have encouraged the improvement of student's writing and speaking skills in your courses.
c. Curriculum development
d. Self-evaluation and/or development
e. Strengths and weaknesses as a teacher
f. Instructional workload
g. Student reaction
h. Other

Areas II through VI will be collectively weighted $25 \%-40 \%$.

II. Scholarship: For evaluation purposes, Department members should provide written documentation of scholarship activities. Scholarship of Department members will be viewed broadly, in accordance with Boyer's four separate but overlapping functions: 
a. Scholarship of Discovery - Work that contributes to the stock of human knowledge and to the intellectual climate of the University, including, but not limited to, papers published in refereed publications or presented at professional meetings.

b. Scholarship of Integration - Work that is interdisciplinary, interpretive, and/or seeks to integrate or synthesize. Making connections across the disciplines, placing academic specialties in larger context, illuminating data in a revealing way, and educating non-specialists. Work that seeks to interpret, draws together, and brings new insight to bear on original research.

c. Scholarship of Application - Academic work or service that serves the larger community, that is tied directly to one's special field of knowledge and which relates to, and flows out of, one's professional activity. Investigation that responds to the questions "How can knowledge be responsibly applied to consequential problems of society?" or "How can knowledge be helpful to individuals as well as institutions?"

d. Scholarship of Teaching - Evaluation of a departmental member's teaching performance may include but need not be limited to the following elements:

1. Staying well informed and steeped in the knowledge of one's field.

2. Demonstrating that pedagogical procedures are carefully planned, continuously examined, and related directly to the subjects taught.

3. Demonstrating successful implementation of the Seven Principles of Good Undergraduate Teaching.

III. Other professional development activities such as attendance at conferences, carrying out grant projects, memberships/offices held in professional associations, and other activities related to your profession.

IV. Community Service:

a. Professional and other

1. Invited lectures or presentations to members of community organizations, participation on community boards of advisors

2. Other outreach activities, volunteerism activities that build ties between town and gown.

V. University and Department Service:
a. Membership and participation on committees
b. Special projects and ad hoc appointments
c. Service as a mentor of probationary faculty

VI. Miscellaneous:
a. Honors, award, etc.
b. Progress toward terminal degree (where appropriate)

The preceding are the specific criteria used to evaluate all Department members. Although each Department member will receive an evaluation in categories I through VI, it is recognized that contributions in these areas will differ, depending on the nature of each member's appointment, and his or her unique strengths and interests.

A post-tenure review will encompass an entire five-year period, and will focus on each faculty member's activities in accordance with his or her plans, interests, and available opportunities. 